\title{
A NEW LATE MIOCENE PLANT ASSEMBLAGE FROM MESSARA BASIN (CRETE, GREECE)
}

\author{
Zidianakis G., Iliopoulos G., Fassoulas C. \\ Natural History Museum of Crete, University of Crete, PO Box 2208, 71409, Irakleio Crete, \\ giannizidi@yahoo.gr,gi6@nhmc.uoc.gr,fassoulas@nhmc.uoc.gr
}

\begin{abstract}
A rich terrigenous plant assemblage was recently excavated from early Tortonian deposits at Messara basin, southern Crete. The macro-remains are perfectly preserved as impressions or carbonized compressions in poorly lithified and locally laminated, blue-green clays with an age of at least 10.5 Ma and thus can be considered as the oldest plant assemblage found in Crete todate. Gymnosperms are represented by the families of Pinaceae (pine needles and winged seeds), Cupressaceae and Taxodiaceae (leafy twings of Taxodium). Besides, 19 different angiosperm taxa of trees and shrubs have been also determined. Fagaceae is the most diversified with foliage of beech and several deciduous and evergreen oaks, while Myricaceae contribute mainly as abundant leaf remains of Myrica lignitum. Accessory elements of evergreen Lauraceae (Daphnogene polymorpha), sclerophyllus shrubs of Buxaceae (Buxus pliocenica) and various deciduous dicotyledonous such as Populus crenata, Liquidambar europaea, Carya minor and Acer pseudomonspessulanum are well documented. Leguminosae is recorded by a significant number of various small leaflet imprints. Therefore, the recovered remains indicate swampy forest habitats dominated by hygrophilic woody plants of Taxodium and Myrica, while in the surrounding plains and slopes a mixed mesophytic forest with a relatively low proportion of evergreen plants occurred in early-Late Miocene times in Crete depicting a moderately humid, warm-temperate nature for the climate.
\end{abstract}

Key words: plant fossils, palaeoflora, palaeovegetation, Miocene, Pitsidia, Crete, Messara.

\section{Introduction}

The island of Crete is part of the Hellenic mountain chain formed during the late stages of Alpine orogenesis. During the middle Miocene the area was affected by intense crustal extension as a result of the retreatment of the African plate subduction and the lateral extrusion of the Anatolian plate (Angelier et al., 1979; Fassoulas, 2001; Meulenkamp, 1994). Fragmentation of landmasses resulted in the development of multi-oriented basins filled by Neogene and Quaternary sediments of various origins. For several decades, lignite deposits and other terrestrial sediments had addressed the possibility for the existence of terrestrial plant macro-remains in some of these basins; however, until recently these basins had not been extensively studied as in other places of Greece. Despite the local character of such fossil records and the doubtless inequitable representation of ancient vegetation, they provide invaluable information about the history and distribution of the floristic elements and offer a great potential for identifying past environmental signals. The first comprehensive reports on Cretan plant macro-fossils derive from the integrated study on the diversified late Tortonian plant assemblage of Makrilia sediments, in eastern Crete (Sachse \& Mohr, 1996; Sachse et al., 1999; 


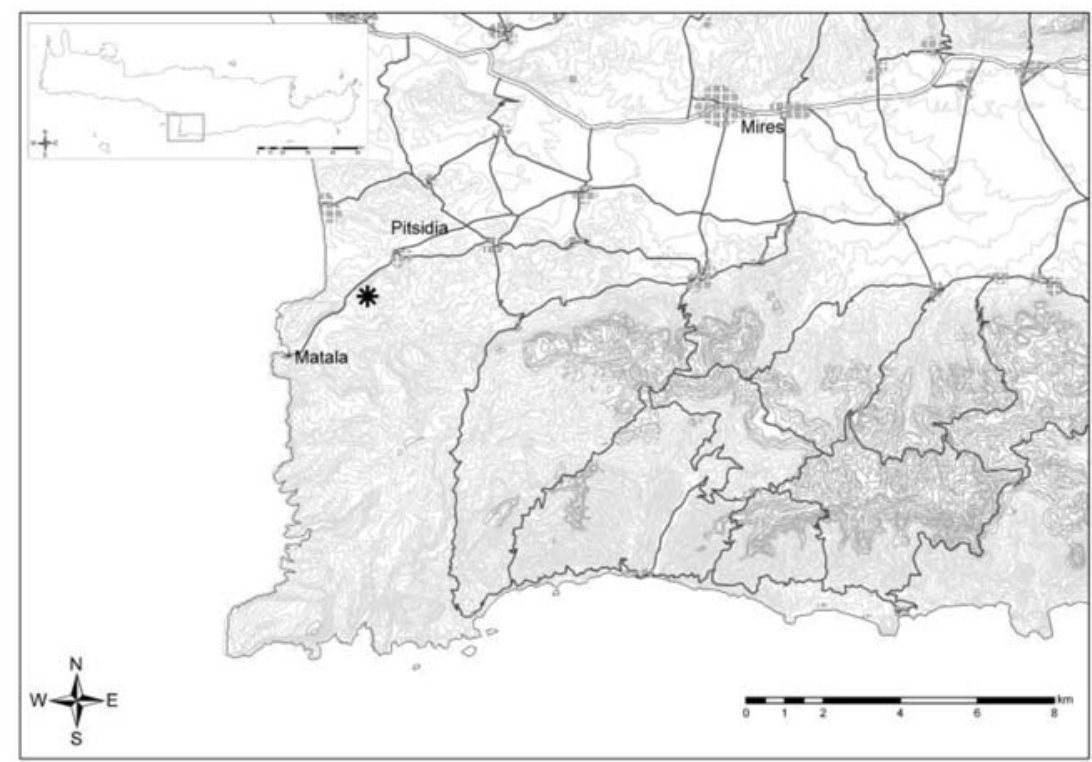

Fig. 1: Generalised topographical map of Eastern Messara basin. The black star indicates the exact position of the Pitsidia fossiliferous locality, southwest of the village Pitsidia.

Sachse, 2004). A few years later, Zidianakis et al. (2007) described a Late Tortonian-Early Messinian palaeoflora from the area of Vrysses in western Crete.

In this preliminary report we describe a new rich terrigenous plant assemblage, excavated recently in Messara basin, at the southern part of central Crete which consists mainly of foliage and diaspores. Terrestrial assemblages have been already found in the past at the eastern margin of the basin at the locality Kastelios hill near Kastelliana village. This locality is well known for its Valesian mammalian fauna (De Bruijn et al., 1971). Hitherto, data on the past plant cover of the basin had been extremely poor, limited exclusively to a few pollen spectra analyses (Benda et al., 1974; Van der Weerd, 1983; Sen et al., 1986). The plant bearing sediments of this study are located near the village Pitsidia in the southwest part of the basin (Fig. 1) and are considered to be early Tortonian or even late Serravallian in age (Kröger, 2004). If this dating is accurate, Pitsidia assemblage will constitute the oldest plant macro-remains that have been ever found on the island and thus can shed light to the palaeoenvironment of an unknown period of the geological history of the Island.

\section{Geographical and stratigraphical settings}

Messara basin, located at the southern part of central Crete, was originally formed during the Neogene as part of a larger basin extending northwards to the area of the present Heraklion basin. Tectonic processes during the early Pliocene separated these two basins with the development of the east-west central Heraklion Ridge (Fassoulas, 2001). Extending in an east-west orientation, Messara basin nowadays covers an area of about $360 \mathrm{~km}^{2}$ bounded by the Psiloritis Mountains and the central Heraklion Ridge to the north, the Asteroussia Mountains to the south and the foothills of Dicti Mountains to the east. Westwards the basin expands into the Libyan sea.

The stratigraphic development of the Neogene sediments in Messara basin had been the subject of 
various studies in the past (e.g., Meulenkamp et al. 1979; ten Veen and Postma, 1999 and Kröger, 2004). According to these studies, the oldest sediments lie unconformably on the basement, Mesozoic to Paleogene, rocks composed mainly of limestone and flysch of the Tripolitza nappe (Creutzburg and Seidel, 1975, Bonneau, 1984). They comprise thick successions of siliciclastic, carbonate and marl deposits of terrigenous and mainly marine origin. These sediments have been separated into two formations, the Ambelouzos and Varvara formations (Meulenkamp, 1979; Meulenkamp et al., 1979; ten Veen and Postma, 1999).

The area, where the fossiliferous beds of Pitsidia are situated, is characterized by low hills dissected by ephemeral creeks. The studied outcrop constitutes a thick succession of terrigenous clastics, estuarine and shallow to open marine sediments which can be divided into 3 main lithostratigraphic units. The lower unit comprises mainly overbank river deposits and presents an alternation of conglomerates, sands, clays and silts that originated from the metamorphic rocks of the nearby mountains. The total thickness of this sequence remains unknown. The middle unit consists of successions of conglomerate and sand layers which indicate coastal, estuarine and shallow marine depositional environments. In the upper unit shallow marine bioclastic (mainly red algae) limestones are found. The first two units can be well correlated with Kröger's (2004) LFA1 unit, whereas the third one matches with his LFA2 unit.

In the lower unit a 5m thick layer of blue-green, poorly lithified and locally laminated clays and silty clays contains a large number of land plant macro-remains, while lack of marine fossils clearly indicates its terrigenous origin. This layer overlies fine sand, while at the top a thin coarse sand layer interrupts the low energy sedimentation which continues above it with a $30 \mathrm{~cm}$ silty layer that also contains plant remains. The silt gradually turns into sand and for the next two meters a succession of conglomerates, sands and silts dominates.

Kröger (2004) using Sr isotope chronostratigraphy examined the bioclastic limestones of the area nearby the fossiliferous outcrop, southwest of Pitsidia village. The age of the base of these limestones which coincide with the limestone of our third unit was determined as early Tortonian (around 10.5 Ma). Consequently, the age of the fossiliferous layer can be presumed as older than $10.5 \mathrm{Ma}$, probably early Tortonian. Therefore, this determination supports the statement that the Pitsidia plant assemblage can be considered as the oldest recovered on the island, and in South Greece todate.

\section{Material and methods}

The terrigenous plant assemblage from Pitsidia is represented by at least 500 specimens that have been collected so far, comprising mainly of foliage (impressions, sporadically carbonized compressions) and less frequently of inflorescences, shoots, fruits and seeds. The material is quite damaged and is characterized by numerous, small in size, leaf fragments which are found scattered throughout the fossiliferous clays. The plant fossils are extremely abundant and in a few cases, the quality of preservation is excellent. Such specimens are exceptionally preserved, and thus cuticle remains are clearly detectable. The studied material is housed in the collections of the Natural History Museum of Crete, and hence the specimens are referred with the collection numbers of the Museum.

The taxonomic determinations established in this study are based exclusively on the gross morphological characters of the gathered specimens, whereas special attention is paid to the morphological details of lamina venation and margin outline of the leaves. The used morphological terminology is based on the descriptions of Hickey (1973), Dilcher (1974) and L.A.W.G. (1999), while the taxonomical arrangement of the angiosperms follows the system proposed by Takhtajan (1987). 


\section{Floristic composition}

The Pitsidia assemblage, apart from the great number of specimens, is considered to be fairly diverse as more than 25 taxa have been identified at this preliminary stage, including two ferns or ferns allied, at least four gymnosperm and 19 angiosperm taxa (Table 1). Among them, the families of Myricaceae and Pinaceae are clearly the most abundant, while Fagaceae, Taxodiaceae, Salicaceae, Altingiaceae and Lauraceae are quite common. Other families like Cupressaceae, Sapindaceae, Leguminosae, Buxaceae, Juglandaceae, Poaceae vel. Cyperaceae and probably Ulmaceae have been also recognized although their occurrence is less frequent.

Pteridophyta are represented by a single fragment of a sterile front, deeply pinnatifid (Fig. 2a) which is attributed to the first occurrence of fern macro-fossils on the island and a jointed, unbranched, aerial stem assigned to the genus Equisetum L (Fig. 2b).

The presence of gymnosperms in the assemblage is demonstrated by both reproductive and vegetative organs. The genus Pinus L. is documented by well distinguishable needles in fascicles of three (Fig. 2c) that are particularly numerous in the fossiliferous layers, together with a few winged seeds (Fig. 2f). The needles are quite long and remarkably broad (10-20mm) with prominent basal leaf sheaths which are always persistent. In the Greek Neogene, almost identical needle fascicles have been reported by Unger in 1867 from the brown-coal bearing sediments of Kymi on Euboea Island. He classified this type of needles to the fossil species Pinus holothana Unger. Moreover, a large number of fragments of long, sterile shoot axes of cryptomerioid type along with some terminal parts of shoots with lanceolate bifacial leaves indicate the occurrence of Taxodiaceae family (Fig. 2d). We tend to believe that all these shoots correspond better with the genus Taxodium Rich.

Angiosperms, which apparently prevail, are documented either by numerous leaves and leaflets or less frequently by inflorescences and fruits. Myrica lignitum (Unger) Saporta is the floristic element that predominates by far the assemblage (Fig. 2g). The fossil leaves that correspond to this ancient species represent approximately 50 per cent of the total recovered plant material. However, at the moment it is difficult to judge to what extent this monotonous appearance is a result of taphonomic bias. Apart from the numerous records, it worth's noting as well the amazing variance in lamina shape, size, and type of margin demonstrated by the recovered foliage. It is generally accepted that although Myrica lignitum consists a very common and wide spread element of European Neogene floras, the evolutionary linage of this species and its relation to modern allies has not been fully resolved so far. Nevertheless, the majority of the authors agree that it should be considered as a typical swamp or riparian element which can survive periodical and long-lasting floods (Kovar-Eder et. al, 2001; Krenn, 1998; Kvaček et. al 2004). Besides Myrica lignitum, another component of the Myricaceae family is present: the well distinguishable Comptonia difformis (Sternberg) Berry with the typical deeply pinnately lobed leaves (Fig. 2h). Actually, the presence of this element in the Neogene of Crete is reported here for the first time.

The family Fagaceae is by far the most diversified in the assemblage. It comprises of at least one species of beech and four other different oak species. In particular the beech Fagus type attenuata (Fig. 2i) and the deciduous oak, Quercus roburoides Gaudin (Fig. 2j), are well documented. It worth's noting that this is also the first report for the presence of roburoid oaks as leaf macro-remains from the Neogene sediments of Crete and probably the earliest from the Greek Neogene. On the other hand, the evergreen sclerophyllous $Q$. mediterranea Unger (Fig. 2m) and Q. drymeja Unger (Fig. 2o) are less frequent. Unlike roburoid oaks, $Q$. mediterranea can be considered, with reasonable safety, as a widespread element in the Upper Miocene throughout Crete, since it has been also reported from Vrysses in the western and from Makrilia in the eastern part of the island. 
Table 1. The floristic composition of Pitsidia plant assemblage.

\begin{tabular}{|c|c|c|c|c|c|}
\hline Nr. & Family & Genus & Species & Type & No of specimens \\
\hline \multicolumn{6}{|c|}{ Pteridophyta } \\
\hline 1 & Equisetaceae & Equisetum & $\mathrm{sp}$. & stem & 1 \\
\hline 2 & fam. indet. & --- & --- & front & 1 \\
\hline \multicolumn{6}{|c|}{ Gymnospermae } \\
\hline 3 & \multirow{2}{*}{ Pinaceae } & Pinus & sp. & needles in fasc. of 3 & 117 \\
\hline 4 & & Pinus & sp. & winged seeds & 4 \\
\hline 5 & Taxodiaceae & Taxodium & sp. & leafy shoots & 10 \\
\hline 6 & Cupressaceae & gen.indet. & --- & leafy shoots & 3 \\
\hline \multicolumn{6}{|c|}{ Angiospermae } \\
\hline 7 & Lauraceae & Daphnogene & polymorpha & leaves & 8 \\
\hline 8 & \multirow{2}{*}{ Altingiaceae } & Liquidambar & europaea & leaves & 4 \\
\hline 9 & & Liquidambar & $s p$ & infructescences & 6 \\
\hline 10 & \multirow{5}{*}{ Fagaceae } & Fagus & type attenuata & leaves & 10 \\
\hline 11 & & Quercus & roburoides & leaves & 22 \\
\hline 12 & & Quercus & mediterranea & leaves & 5 \\
\hline 13 & & Quercus & drymeja & leaves & 3 \\
\hline 14 & & Quercus & ?kubinyii & leaves & 3 \\
\hline 15 & \multirow{2}{*}{ Myricaceae } & Myrica & lignitum & leaves & 205 \\
\hline 16 & & Comptonia & difformis & leaves & 2 \\
\hline 17 & Juglandaceae & Carya & minor & leaflets & 2 \\
\hline 18 & \multirow{2}{*}{ Salicaceae } & Salix & $s p$ & leaves & 3 \\
\hline 19 & & Populus & crenata & leaves & 5 \\
\hline 20 & \multirow{2}{*}{ Leguminosae } & Podocarpium & podocarpum & leaflet & 1 \\
\hline 21 & & gen.indet. & --- & leaflet & 1 \\
\hline 22 & Buxaceae & Buxus & pliocenica & leaves & 2 \\
\hline 23 & Sapindaceae & Acer & pseudomonspessulanum & leaf & 1 \\
\hline 24 & Ulmaceae & ?Zelkova & zelkovaefolia & leaf & 1 \\
\hline 25 & $\begin{array}{l}\text { Poaceae vel. } \\
\text { Cyperaceae }\end{array}$ & gen. indet & --- & leaves & 2 \\
\hline
\end{tabular}




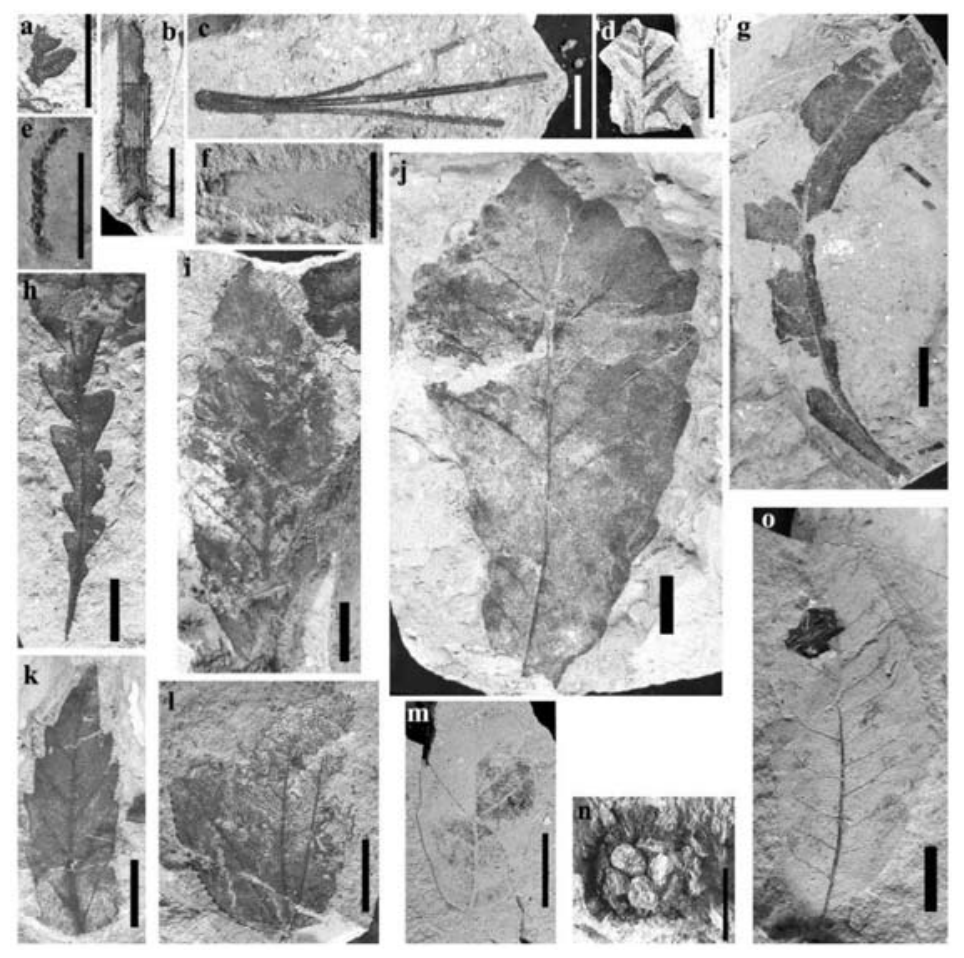

Fig. 2: Plant remains from Pitsidia outcrop: a) Fern no 31.4.2.109a; b) Equisetum sp. no 31.4.2.014; c) Pinus sp. (needles) no 31.4.2.472; d) Taxodium sp. no 31.4.2.219; e) Cupressaceae no 31.4.2.132; f) Pinus sp. (seed) no 31.4.2.322ii; g) Myrica lignitum no 31.4.2.060; h) Comptonia difformis no 31.4.2.105; i) Fagus type attenuata no 31.4.2.317; j) Quercus roburoides no 31.4.2.322i; k) Quercus cf. kubinyii no 31.4.2.323; 1) Liquidambar europaea no 31.4.2.273; m) Quercus mediterranea no 31.4.2.272; n) Liquidambar (fruit) no 31.4.2.278; o) Quercus drymeja no 31.4.2.206. Scale bars $1 \mathrm{~cm}$.

In the group of common floristic elements of the assemblage we can include another broad-leaved deciduous tree, Liquidambar europaea A. Braun. In general, the recovered population demonstrates foliage with exclusively three lobes (Fig. 21). A thorough examination of macro-fossil records in numerous European localities has shown that three-lobed leaf forms predominated during the early Neogene, while this trend gradually changed in the Late Miocene and Pliocene as foliage with five or seven lobes became more frequent (Büžek, 1971). In Pitsidia, the robust occurrence of the genus Liquidambar L is supported by the recovery of spherical fruiting heads which consist of dense clustered, elongate, wedge-shaped fruits (capsules). Their systematic position is positively confirmed by the characteristic honeycomp-like shape of the peripheral rim that one of the specimens displays (Fig. 2n). Actually, it can be concluded to a certain extent that these infructescences are related with the three-lobed leaves of L. europaea and probably they consist parts of the same species.

In this preliminary study, the occurrence of lauraceous elements is surprisingly rare. The morphospecies Daphnogene polymorpha (A. Braun.) Ettigshausen is the only component of the Lauraceae family identified till now (Fig. 3a). This weak representation can be ascribed either to the influence of an already well-established seasonal climate with a pronounced dry or cool period during the year, or perhaps to taphonomic bias. 

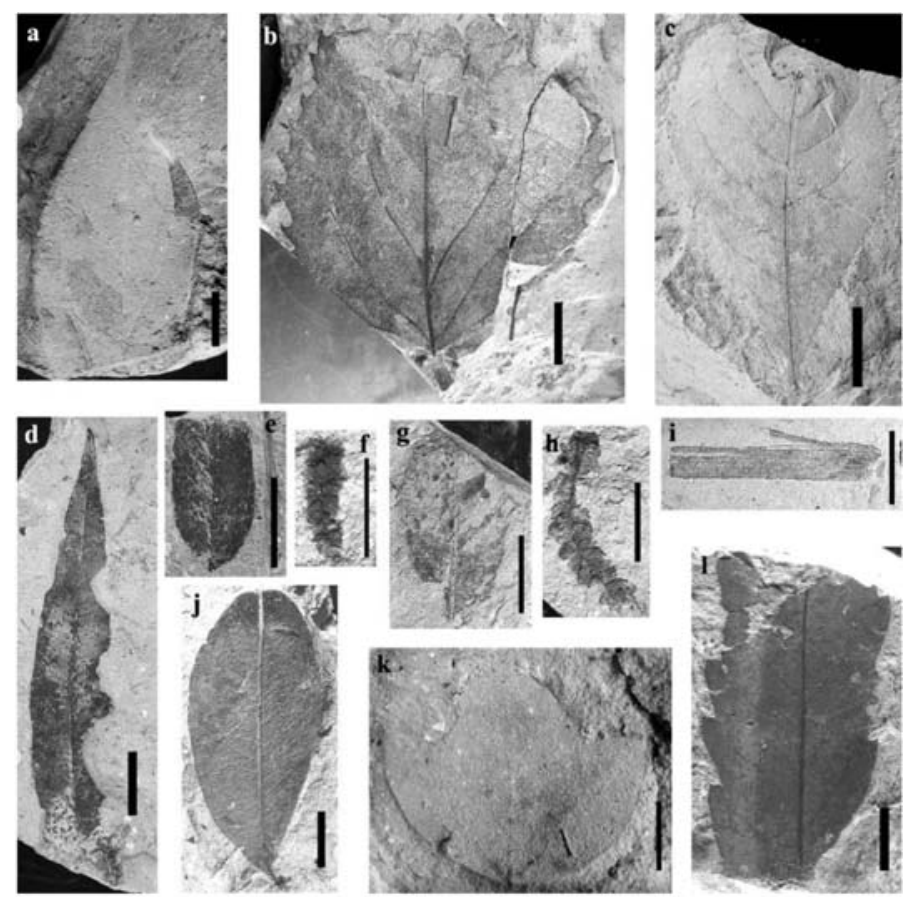

Fig. 3: Plant remains from Pitsidia outcrop: a) Daphnogene polymorpha no 31.4.2.263; b) Populus crenata no 31.4.2.349; c) Carya minor no 31.4.2.471; d) Salix sp. no 31.4.2.354; e) Podocarpium podocarpum no 31.4.2.229; f) Catkin probably of Myrica no 31.4.2.098; g) Buxus pliocenica no 31.4.2.269; h) Catkin probably of Betulaceae no 31.4.2.192; i) Poaceae vel. Cyperaceae no 31.4.2.312; j) Leguminosae leaflet no 31.4.2.207; k) Acer pseudomonspessulanum no 31.4.2.211; 1) cf. Zelkova zelkovaefolia no 31.4.2.267. Scale bars $1 \mathrm{~cm}$.

The family of Salicaceae is represented by the genera Populus L. (Fig. 3b) and Salix L. (Fig. 3d). The former comprises of tri-veined leaf forms with large teeth which are quite similar with the poplar foliage remains from Gabbro, in central Italy, described by Berger (1957) under the name P. crenata Berger. In the Greek Neogene, these leaves correspond better to the population from the Late Miocene flora of Vegora in Macedonia (northern Greece), assigned to the common poplar species Populus populina (Brongniart) Knobloch (Kvaček et al., 2002). Nevertheless, taking into account the great leaf variation that most of the modern poplar species demonstrate, it is not quite clear whether leaf forms like those recovered in Pitsidia represent a separate ancient species (i.e. P. crenata) or consist part of the leaf variation inside the common species P. populina.

An account of pollen grains from several sediment samples from the Kastellios hill sections, indicates that the family Juglandaceae in Messara basin was quite abundant and widely diversified (Benda et al., 1974; van der Weerd, 1983; Sen et al., 1986). These sections, located in the easternmost borders of the basin, are considered to be very close or even identical in age with the fossiliferous layers from Pitsidia. Surprisingly, in the Pitsidia assemblage, the family Juglandaceae by no means dominates, comprising until now merely of two leaflets that probably belong to the species Carya minor (Saporta et Marion) Saporta (Fig. 3c).

The family of Leguminosae is represented by the well known element Podocarpium podocarpum (A. Braun) Herendeen (Fig. 3e), and a few small leaves with entire margin and more or less asym- 
metrical basis (Fig. 3j). Especially Podocarpium podocarpum is only documented by a sole incomplete leaflet. Its venation, which is characterized by a pair of prominent basal secondary veins originating at acute angles and extending parallel to the lamina margin, allowed us to attribute this specimen with certainty to this species. After numerous taxonomic treatments by many authors, this taxon seems to represent an extinct genus of the Leguminosae family and does not correlate with any extant legume (Herendeen, 1992 a, b; Wang et. al, 2007).

In addition, a few interesting, though very poorly represented accessory elements, have been collected from Pitsidia deposits that correspond to the ancient morpho-species Acer pseudomonspessulanum Unger (a sole leaf specimen) (Fig. 3k), Buxus pliocenica Sapota et Marion (two leaf specimens) (Fig. 3g) and probably Zelkova zelkovaefolia (Unger) Kotlaba (one leaf specimen) (Fig. 31).

Finally, we must point out that numerous findings consisting of leaf and fruit remains as well as excellent-preserved compressions of male inflorescences (mainly catkins), that have a questionable affinity are not presented in this study as their taxonomic determination was not considered plausible (Figs. 3f, 3h). In the future further investigations will be undertaken including leaf cuticular analysis and catkin pollen examination in order to decipher the affinities of this unidentified material and furthermore, to confirm or even improve the identifications of the plant remains described above.

\section{Vegetation reconstruction and paleoclimate}

In fossil plant assemblages, the taphonomic processes during sedimentation bring together plant remains originating from different habitats. In order to obtain reliable results about the regional vegetation structure and the plant associations, a number of geological and taphonomical disciplines (e.g. Ferguson, 1985; 2005; Gastaldo, 2001; Greenwood, 1991; Spicer, 1989) along with the study and evaluation of numerous palaeofloras throughout Neogene is also necessary to be taken into account. According to the stratigraphical architecture and deposit lithologies that occur in Pitsidia and the adjacent areas, a characteristic estuary landscape interfingering with backswamp, floodplain, riverbank and probably bog habitats is well documented (Kröger, 2004). These depositional settings are in complete agreement with the relative abundance of the floristic elements in the assemblage and the autoecology of the identified taxa.

Within the deltaic plain, at a certain distance from the sea shore, typical backswamp systems were occurring. The permanent waterlogged soils were inhabited by a more or less closed canopy forest, which had been probably dominated by the typical swampy conifer Taxodium. This could have been either the sole canopy component or in some elevated areas it could have been associated with broadleaved elements like Liquidambar europaea or even with pine trees. In the understorey of the swamp plant community, only a few taxa probably grew like Myrica lignitum and Comptonia difformis, where the former clearly predominated.

Taking into account the extreme abundance of Myrica macro-remains in the assemblage, and the fact that many living species of this genus are considered as early succession elements with nitrogen-fixing nodules at the roots, which enable the plants to colonize soils that are very poor in nitrogen content, we expect a widespread occurrence of acid, shrub covered bogs in the Pitsidia wetlands. In these habitats, with low nutrient supply and ground water level lying near or above the earth surface, a dense population of Myrica lignitum apparently prevailed.

The active river channels and the allied oxbow ponds have been lined by a probably oligotypic gallery forest predominated in particular by Salicaceae (Populus crenata and Salix) and Liquidambar 
europaea. Furthermore, the presentation of Myrica lignitum in the understory of this riparian formation is quite possible, while Equisetum seems to constitute a usual element associating among others with ferns in the herb layer.

Beyond the influence of flooding, on the slopes of the adjacent hills, zonal vegetation was quite diverse but not uniform, depending on the moisture and fertility of the soil as well as on the sun exposition. On moderately moist substrates a widespread mixed mesophytic forest probably occurred, composed mainly of broad-leaved deciduous trees and an extremely low proportion of evergreen elements. This temperate forest clearly is related phyto-sociologically with the Class Querco-Fagetea. Except from the attenuata-type beech trees, the deciduous oaks and especially Quercus roburoides, were predominating in the forest canopy creating an association that could be named Fagetum attenuatae - Quercetum mixtum. The evergreen Daphnogene polymorpha and presumably the deciduous Podocarpium podocarpum, Zelkova zelkovaefolia and Carya minor represent the only accessory elements that have been found in the Pitsidia assemblage so far. The shrub layer was poorly developed probably consisting of both deciduous (Comptonia difformis) and evergreen (Buxus pliocenica) elements. On drier substrates, this ancient association seems to have been replaced by a well-developed xerophytic woodland. The characteristic species in the canopy were the sclerophyllous oaks of the Quercus mediterranea/Q. drymeja group, while shrubs of similar physiognomy were occurring in the understorey including Acer pseudomonspessulanum, Buxus pliocenica, $\mathrm{Cu}-$ pressaceae and Leguminosae. This plant association can be referred as the Quercetum mediterraneum association (Class of Quercetea). On southern slopes and in areas with poor substrate, the pine trees were probably forming pure stands, although the huge amount of pine needles and diaspores in the assemblage allows us to suppose that this element was spreading also on sites with higher soil fertility and moisture, possibly close to wetland, forming a mixed oak - beech - pine forest.

As it is revealed by this preliminary study, the Pitsidia assemblage floristically is characterized by the apparent predominance of 'arctotertiaty' elements, whereas thermophilic elements are quite rare (i.e. Daphnogene, Taxodiaceae). Besides, the zonal vegetation in the area consists of both mixed mesophytic forests with a relatively high percentage of broad-leaved deciduous taxa and sclerophyllous woods. The simultaneous occurrence of these units and elements attests to a relatively humid, warm-temperate climate with only one weakly dry period during the year (Cfatype climate sensu Köppen, 1931), which actually is not directly comparable to the present Mediterranean type.

\section{Comparison with other Neogene flora of Crete}

Two outcrops with Neogene terrestrial plant macro-remains have been known in Crete so far. The oldest, situated near Makrilia village in the eastern part of the island, is dated as Late Tortonian, approximately 7.7 to 8.6 million years ago, while the youngest found in the western part of the island near Vrysses village is estimated to be of latest Tortonian - Early Messinian age (ca 7.5 - 6.0million years). Generally speaking, the Pitsidia flora varies rather profoundly from the other two due to its pronounced swampy-riparian character. Floristically they only share a few common elements, like Quercus mediterranea, Acer pseudomenspessulanum, Buxus pliocenica and Daphnogene polymorpha. However, all assemblages from Crete include without any doubt a prominent proportion of sclerophyllous woody plants except from mesic ones, reflecting in this way the significant occurrence of warm sub-humid habitats on the island during the Late Neogene.

Furthermore, the Makrilia assemblage is obviously closer, floristically and also physiognomically, to that of Pitsidia as they share many elements like the hydrophilic Myrica lignitum, Taxodium, Eq- 
uisetum, Populus, Salix, and some, more or less, mesic arboreal elements including Fagus type attenuata, Quercus kubinyii, Podocarpium podocarpum. Of course, there are a few significant dissimilarities between them as well. Contrary to Pitsidia, the Makrilia flora presents an apparently small-leaved character and illustrates a remarkable higher diversity extending to 70 different identified taxa. Especially, the mixed mesophytic forests comprise a great number of various deciduous accessory elements like Zelkova zelkovaefolia, Ulmus, Carpinus, Fraxinus and Tilia. Moreover, the families Lauraceae and Magnoliaceae are well diversified in Makrilia flora, accompanied by other thermophilic elements like Engelhardieae, Tetraclinis salicornioides and Asterocalyx styriacus. Likewise, the sclerophyllous elements are more frequent and more diverse.

On the other hand, the assemblage of Vrysses is dominated by the sclerophyllous Quercus mediterranea and numerous fragments of pine needles. Both three-lobed leaves of Acer pseudomonspessulanum and segments of Tetraclinis are quite common while various elements like Daphnogene polymorpha, Buxus pliocenica, Juglans, Populus tremula and a few leaflets of Leguminosae are also present. In addition, typical swampy plants are completely absent. Thus, contrary to Pitsidia, the flora of Vrysses demonstrates a more sub-humid character with many xeromorphic elements that indicate the occurrence of well-developed sclerophyllous plant associations. Also, the mesophytic woodland palaeocoenoses are clearly less diverse and probably poorly developed. Tall deciduous trees like beech and oaks are apparently lacking. Instead only a few deciduous shrubs like Parrotia pristina and Ziziphus ziziphoides seldom occur.

Finally, it is important to notice the strong presence of some conspicuous floristic elements like sweetgum, roburoid oaks and Pine trees with needles in fascicles of three in Pitsidia that are entirely absent from Makrilia and Vrysses ancient macro-floras. In particular the genus Liquidambar is absent even from the pollen spectrum of Makrilia.

\section{Conclusions}

The Late Miocene plant material from the area of Pitsidia in the southern part of central Crete is quite abundant with elements of both autochthonous and allochthonous origin, deposited in an estuary environment. The assemblage comprises of at least 25 different plant taxa, a number which is expected to increase dramatically in the future as, at the moment, this study is in a preliminary stage. It consists mainly of broad-leaved deciduous or evergreen angiosperms and a few conifers and ferns. Leaf remains of Myrica lignitum and pine needles in fascicles of three predominate. Also, Taxodium with sterile shoots, Quercus roburoides, Fagus type attenuata and Liquidambar europaea are considered common elements of the flora. Among the identified taxa, fern macro-remains, 3-needled Pinus, Comptonia difformis, Liquidambar europaea, roburoid oaks, Quercus drymeja and Populus crenata are reported for the first time from the Neogene of Crete. The floristic composition of Pitsidia is in full accordance with the results of earlier pollen grain analyses from contemporary sediments at the eastern border of Messara basin which record the predominance of Myricaceae, Fagaceae and Taxodiaceae elements.

According to the current data, the palaeoflora of Pitsidia indicates the occurrence of extensive swampy and riparian woods throughout the wetlands, together with both deciduous mesophytic and evergreen xerophytic, mid altitude forests at the slopes of the surrounding hills, developed in a relatively warm temperate climate with a weakly developed dry period. So, we are convinced that these new plant findings will provide a unique opportunity to enrich our fragmentary knowledge of the past and emerge a more accurate picture of the vegetation succession and the palaeoenvironmental history of the southernmost European province. 


\section{References}

Angelier, J., Brebion, Ph., Lauriat-Rage, A. and Muller, C., 1979. Late Cenozoic biostratigraphy and neotectonic evolution of Crete. Ann. Géol. Pays Hellén., fasc. 1, 9-17.

Benda, L., Meulenkamp, J.E. and Zachariasse, W.J., 1974. Biostratigraphic correlations in the eastern Mediterranean Neogene. 1.Correlation between planktonic foraminiferal, uvigerinid, sporomorphal and mammal zonations of the Cretan and Italian Neogene, Newsl. Stratigr., 3, 205-217.

Berger, W., 1957. Untersuchungen an der obermiozäne (Sarmatischen) Flora von Gabbro (Monti Livornesi) in der Toskana. Ein Beitrag zur Auswertung tertiärer Blattfloren für die Klima- und Florengeschichte, Palaeontographia Italica, 51, 1-103.

Bonneau, M., 1984. Correlation of the Hellenides nappes in the south - east Aegean and their tectonic reconstruction, Geol. Soc. London, sp. publ., 17, 517-527.

Bůžek, Č., 1971. Tertiary flora of the northern part of Pĕtipsy area (North-Bohemian Basin), Rozpr. Ústřr. Úst. Geol., 36, 1-118.

Creutzburg, N. and Seidel, E., 1975. Zum Stand der Geologie des Praeneogens auf Kreta, N. Jb. Geol. Palaeont. Abh., 149, 363-383.

De Bruijn, H., Sondaar, P.Y. and Zachariasse, W.J., 1971. Mammalia and Foraminifera from the Neogene of Kastellios Hill (Crete). A correlation of continental and marine biozones I, Proc. of the Koninklijke Nederlandse Akademie van Wetenschappen, Amsterdam, 74(5), 1-22.

Dilcher, D.L., 1974. Approaches to the identification of angiosperm leaf remains, The Botanical Review, 40, 1-157.

Fassoulas, C., 2001. The tectonic development of a Neogene basin at the leading edge of the active European margin: the Heraklion basin, Crete, Greece, Journal of Geodynamics, 31, 49-70.

Ferguson, D. K., 1985. The origin of leaf-assemblages, new light on an old problem, Review of Palaeobotany and Palynology, 46, 117-188.

Ferguson, D. K., 2005. Plant Taphonomy: Ruminations on the Past, the Present, and the Future, Palaios, 20(5), 418-428.

Gastaldo, R. A., 2001. Plant taphonomy. In Briggs, D.E.G. and Crowther, P.R., (eds), Palaeobiology II. 314-317, Oxford, Blackwell Scientific Publications, 578pp.

Greenwood, D. R., 1991. The taphonomy of plant macrofossils. In Donovan S. K. (ed.), The Processes of Fossilization. 141-169, New York, Columbia Univ. Press, 303pp.

Herendeen, P. S., 1992a. A reevaluation of the fossil genus Podogonium Heer. In Herendeen, P.S. and Dilcher, D.L., (eds), Advances in Legume Systematics: Part 4. The fossil record. 3-18, London, The Kew Royal Botanic Gardens, 336pp.

Herendeen, P. S., 1992b. Podogonium podocarpum (Al. Br.) Herendeen, comb. nov., the correct name for Podogonium knorrii (Al. Br.) Heer, nom. illeg. (Leguminosae), Taxon, 41, 731-736.

Hickey, L.J., 1973. Classification of the architecture of dicotyledonous leaves, American Journal of Botany, 60, 17-33.

Köppen, W., 1931. Klimakarte der Erde. Grundriss der Klimakunde, $2^{\text {nd }}$ ed., Springer-Verlag, Berlin and Leipzig, 388pp.

Kovar-Eder, J., Kvaček, Z. and Meller, B., 2001. Comparing Early to Middle Miocene floras and probable vegetation types of the Oberdorf N Voitsberg (Austria), Bohemia (Czech Repablic) and Wackersdorf (Germany), Review of Palaeobotany and Palynology, 114, 83-125.

Krenn, H., 1998. Die obermiozäne (pannone) Flora von Paldau, Steiermark, Österreich, Mitt. Abt. Geol. Paläont. Landesmus. Joanneum, 56, 165-271. 
Kröger, K. F., 2004. Sedimentary environments and climate change: a case study (late Miocene, central Crete), Ph.D., Mainz, Johannes Gutenberg-Universität, 224 pp.

Kvaček, Z., Böhme, M., Dvořák, Z., konzalová, M., Mach, K., Prokop, J. and Rajchl, M., 2004. Early Miocene freshwater and swamp ecosystems of the Most Basin (northen Bochemia) with particular reference to the Bílina Mine section, Journal of the Czech Geological society, 49(1-2), 1-40.

Kvaček, Z., Velitzelos, D. and Velitzelos, E., 2002. Late Miocene Flora of Vegora Macedonia N Greece, Athens, Korali Publications, 175 pp.

Leaf Architecture Working Group, 1999. Manual of Leaf Architecture - morphological description and categorization of dicotyledonous and net-veined monocotyledonous angiosperms, Washington, Smithsonian Institution, 67pp.

Meulenkamp, J. E., Dermitzakis, M., Georgiadou Diceoulia, E., Jonkers, H. A. and Beöger, H., 1979. Field Guide to the Neogene of Crete. Athens, Department of Geology and Paleontology, University of Athens, Series A, 32pp.

Meulenkamp, J.E., van der Zwaan, G.J., and van Wamel, W.A., 1994. On Late Miocene to Recent vertical motions in the Cretan segment of the Hellenic arc, Tectonophysics, 234, 53-72.

Sachse, M., 2004. Die neogene Mega- und Mikroflora von Makrilia auf Kreta und ihre ussagen zur Klima- und Vegetationgeschichte des östlichen Mittelmeergebietes, Flora Tertiaria Mediterranea, 6(12), 1-323.

Sachse, M. and Mohr, B. A. R., 1996. Eine obermiozäne Makro- and Mikroflora aus Südkreta (Griechenland), und deren paläoklimatische Interpretation-Vorläufige Betrachtungen, Neues Jahrbuch für Geologie und Paläontologie Abhandlungen, 200, 149-182.

Sachse, M., Mohr, B. and Suc, J.-P., 1999. The Makrilia flora. A contribution to the Neogene history of the climate and vegetation of the Eastern Mediterranean, Acta Palaeobotanica, Suppl. 2, 365-372.

Sen, S., Valet, J. P. and Ioakim, C., 1986. Magnetostratigraphy and biostratigraphy of the Neogene deposits of Kastellios hill (central Crete, Greece). Palaeo, 53, 321-334.

Spicer, R. A., 1989. The formation and interpretation of plant fossil assemblages, Advances in Botanical Research, 16, 96-191.

Takhtajan, A., 1987. Systema Magnoliophytorum, Leningrad, Editoria Nauka, 439pp.

ten Veen, J.H., and Postma, G., 1999. Neogene tectonics and basin fill patterns in the Hellenic outer-arc, Basin Research, 11, 223-241.

Van der Weerd, A., 1983. Palynology of some Upper Miocene and Pliocene formations in Greece, Geol. $J b ., 48(B), 3-63$.

Unger, F., 1867. Die fossile Flora von Kumi auf der Insel Euboea, Denkschriften der Kaiserlichen Akademie der Wissenschaften. Math.- naturwiss, 27, 27-90.

Wang, Q., Dilcher, D. L. and Lott., T.A., 2007. Podocarpium A. Braun ex Stizenberger 1851 from the middle Miocene of Eastern China, and its palaeoecology and biogeography, Acta palaeobotanica, 47(1), 237-251.

Zidianakis, G., Mohr, B.A.R. and Fassoulas C., 2007. A Late Miocene leaf assemplage from Vrysses, Western Crete, Greece, and its paleoenvironmental and paleoclimatic interpretation, Geodiversitas, 29(3), 351-377. 